\title{
Identification of Brachyspira spp. in the cecum of broiler chickens using histology and in situ diagnostic assays
}

\section{Identificação de Brachyspira spp. em cecos de frangos de corte por meio de histologia e ensaios diagnósticos in situ}

\author{
Monica Regina de Matos ${ }^{1 *}$; Aline Patrícia Grzegozevski²; Alessandra da Cruz²; \\ Arthur Colombari Cheng2; Amanda Gerelli2; Carla Fusco²; Leonardo Gruchouskei3; \\ Aline de Marco Viott ${ }^{4}$
}

\section{Highlights}

Brachyspira spp. is a potential pathogen of birds, swine, and humans.

There is a high frequency of Brachyspira species in the Western region of Paraná state.

FISH and IHC assays can detect and identify Brachyspira spp. efficiently in intestinal segments of chickens.

\begin{abstract}
The genus Brachyspira corresponds to the group of bacteria formerly classified into the genus Serpulina and includes several commensal and pathogenic intestinal spirochetes that affect pigs, poultry, and other animal species, including humans. In birds, some pathogenic species of this genus causes a condition known as avian intestinal spirochetosis, which remains underdiagnosed, thereby causing serious economic losses. Brachyspira is a fastidious organism that necessitates the employment of fast and efficient identification techniques. The aim of this study was to identify Brachyspira spp. using histology, immunohistochemistry $(\mathrm{IHC})$ and fluorescence in situ hybridization (FISH) in formalin-fixed paraffin embedded (FFPE) tissue samples from the cecum of commercial poultry. Samples were collected from 129 birds aged between 35 and 45 days from commercial broiler farms. For evaluation, routine histology processing (H\&E) and the histochemical technique, periodic acid-Schiff (PAS) were done. Additionally, FFPE tissue samples were evaluated for FISH and IHC. The histological lesions were analyzed and graded after H\&E staining, and the goblet cells were counted and compared using PAS staining with the positive

1 M.e. in Animal Science by the Program of Postgraduate in Animal Science, Universidade Federal do Paraná, UFPR, Palotina, PR, Brazil. E-mail: monica.matos@pucpr.br.

2 Students in Medicine Veterinary, UFPR, Palotina, PR, Brazil. E-mail: alinepatricia718@gmail.com; aledacruz9809@ gmail.com; aarthurcheng@gmail.com; gerelliamanda@gmail.com; carlareginafusco@gmail.com.

3 Technician in Anatomic Veterinary, Universidade Federal da Fronteira Sul, UFFS, Realeza, PR, Brazil. E-mail: leogruchouskei@gmail.com.

4 Profa Dra, Graduate Course in Veterinary Medicine, UFPR, Palotina, PR, Brazil. E-mail: alinedemarco@yahoo.com.br

* Author for correspondence
\end{abstract}

Received: July 08, 2021 - Approved: June 17, 2021 
and negative samples obtained through FISH and IHC. For FISH, probes labeled with Brachyspira spp., B. pilosicoli, B. hyodysenteriae, and B. intermedia were used, whereas rabbit polyclonal antibody specific for Brachyspira spp. was used for IHC. Of 129 samples, 82 were positive with IHC and 86 were positive with $\mathrm{FISH}$. The samples positive for the genus Brachyspira in the FISH technique were tested for B. pilosicoli, B. hyodysenteriae, and B. intermedia in which 56 were positive for B. pilosicoli, 75 for B. hyodysenteriae and 80 for B. intermedia. There was an increase in goblet cells in the samples positive for FISH and IHC. The techniques used were effective and gave corresponding results, thus serving as a fast and efficient tool for diagnosis.

Key words: Avian intestinal spirochetosis. Enteritis. Diagnosis. Histology. Immunohistochemistry. Fluorescence in situ hybridization. Brachyspira spp.

\section{Resumo}

O gênero Brachyspira corresponde ao grupo de bactérias anteriormente classificadas no gênero Serpulina e inclui várias espiroquetas intestinais comensais e patogênicas que afetam suínos, aves e outras espécies animais, incluindo humanos. Em aves, algumas espécies patogênicas desse gênero causam uma condição conhecida como espiroquetose intestinal aviária, que permanece sub-diagnosticada, causando sérios prejuízos econômicos. Brachyspira é um organismo fastidioso que necessita do emprego de técnicas de identificação rápidas e eficientes. O objetivo deste estudo foi identificar Brachyspira spp. usando histologia, imunohistoquímica (IHQ) e hibridização fluorescente in situ (FISH) em amostras de tecido fixado em formalina e embebido em parafina (TFEP) do ceco de aves comerciais. As amostras foram coletadas de 129 aves com idades entre 35 e 45 dias em granjas comerciais. Para avaliação, o processamento histológico de rotina (H\&E) e a técnica histoquímica, ácido periódico-Schiff (PAS) foram realizados. Além disso, as amostras de tecido TFEP foram avaliadas para FISH e IHC. As lesões histológicas foram analisadas e graduadas após coloração H\&E, e as células caliciformes contadas e comparadas pela coloração PAS com as amostras positivas e negativas obtidas por FISH e IHC. Para FISH, foram utilizadas sondas marcadas com Brachyspira spp., B. pilosicoli, B. hyodysenteriae e B. intermedia, enquanto o anticorpo policlonal de coelho específico para Brachyspira spp. foi usado para IHC. De 129 amostras, 82 foram positivas com IHC e 86 foram positivas com FISH. As amostras positivas para o gênero Brachyspira pela técnica de FISH foram testadas para B. pilosicoli, B. hyodysenteriae e B. intermedia, sendo 56 positivas para B. pilosicoli, 75 para B. hyodysenteriae e 80 para B. intermedia. Houve aumento de células caliciformes nas amostras positivas para FISH e IHC. As técnicas utilizadas foram eficazes e deram os resultados correspondentes, servindo assim como uma ferramenta de diagnóstico rápida e eficiente.

Palavras-chave: Espiroquetose intestinal aviária. Enterite. Diagnóstico. Histologia. Imuno-Histoquímica. Hibridização fluorescente in situ. Brachyspira spp. Frango de corte. 


\section{Introduction}

Bacteria of the genus Brachyspira can cause enteric disease in several species of animals; however, they are best described in pigs, where Brachyspira pilosicoli and Brachyspira hyodysenteriae are the primary causative agents of spirochetal colitis and porcine dysentery, respectively (Hampson, Fellstron, \& Thomson 2006). In birds, Brachyspira causes a condition known as avian intestinal spirochetosis (AIS) (Medhanie et al., 2013). Four species of Brachyspira are considered pathogenic to birds Brachyspira intermedia, Brachyspira pilosicoli, Brachyspira alvinipulli and Brachyspira hyodysenteriae and one or more of these species may be concomitantly involved in an infection (Song \& Hampson, 2009; Mappley, La Ragione, \& Woodward, 2014).

The transmission of Brachyspira spp. between different animal species has been verified in poultry, pigs, and rodents, all of which can be colonized from a common environmental source. Thus, rats and mice can transmit B. pilosicoli and B. hyodysenteriae between bird flocks on different farms (Backhans, Jansson, Aspan, \& Fellström, 2011)

AIS affects the cecum and colon of broiler chickens resulting in mild to severe diarrhea. As a result, there is a loss in the overall performance of the birds (Phillips \& Hampson, 2006; Illanes et al., 2016). Research on the morbidity and mortality rates in broiler chickens caused by the Brachyspira species is lacking, leading to a paucity of information on the real impact caused by this agent.

Histological lesions are not well described in birds; however, in affected mammalian species, lesions are usually limited to the colon and cecum and demonstrate neutrophils, plasma cells, and lymphocyte infiltrates in the lamina propria, as well as variable luminal and interstitial hemorrhage. There may be superficial mucosal necrosis and accumulation of neutrophils and mucus at the top of the villi, as well as crypt hyperplasia and abscesses. Large, delicate spirochetes with features typical of Brachyspira spp. can be observed at the top of the villi (Burrough, et al., 2012; Rojas, 2017).

The diagnostic method for AIS is usually bacterial culture followed by biochemical assays. Brachyspira spp. is a proliferative anaerobic bacterium that is difficult to culture. It requires many passages in culture media and several days for purification of the strains. In addition, there are few phenotypic differences between species, which makes identification more complex (Illanes et al., 2016). In a study conducted by Burrough et al. (2012), strongly beta-hemolytic isolates on blood agar were associated with higher virulence, where the animals exhibited increased rates of diarrhea, hemorrhage, and fecal mucus.

The fluorescence in situ hybridization (FISH) technique is rapid and sensitive and allows identification and localization of the causative agent. FISH also allows the number and morphology of bacterial cells to be evaluated and the species to be identified using formalin-fixed tissues. Although its application is fast, thorough controls are essential to ensure the quality of the results (Boye, Jensen, Møller, Leser, \& Jorsal, 1998; Moter \& Göbel, 2000).

Immunohistochemistry (IHC) plays an increasingly important role in diagnostic accuracy by combining immunological and 
biochemical techniques to identify specific components of a tissue. $\mathrm{IHC}$ is used as a complementary study to pathological diagnosis or for scientific research purposes. This technique detects and analyzes tissue components through the reaction of specific antibodies and use of chromogens (color reagents) (Cooper \& Lummas, 2017).

The search for diagnostic techniques that are efficient, easy to apply in the field, and low cost continues. Given this scenario, the objective of this study was to identify bacteria of the genus Brachyspira in broiler chickens using intestinal samples using $\mathrm{IHC}$ and $\mathrm{FISH}$, as well as to describe possible histological alterations in the intestines of animals infected by these agents.

\section{Material and Methods}

This study was approved by the Ethics Committee on Animal Use of the Palotina Sector of the UFPR (CEUA/Palotina) with the protocol number 09/2018 and was conducted in accordance with the Ethical Principles of Animal Experimentation adopted by the National Council for the Control of Animal Experimentation (CONCEA).

\section{Samples}

A total of 129 cecum samples, collected from broilers ranging in age from 35 to 45 days from nine farms, located in two municipalities in western Paraná $\left(24^{\circ} 25^{\prime} 4^{\prime \prime} \mathrm{S}, 53^{\circ} 49^{\prime} 48^{\prime \prime} \mathrm{W}\right.$ and $\left.24^{\circ} 17^{\prime} 2^{\prime \prime} \mathrm{S}, 53^{\circ} 50^{\prime} 24^{\prime \prime} \mathrm{W}\right)$ were used. Ten birds per flock were randomly chosen from the farm (with or without history of diarrhea). Fragments of the cecum were collected, macroscopically analyzed, and fixed in $10 \%$ buffered formalin.

\section{Histology}

For histopathological examination, after 24 hours of fixation in 10\% formalin, the samples were cleaved (four cecum fragments per bird) and processed using the routine histological techniques of dehydration and paraffin embedding. The paraffinized tissues were sectioned into 5- $\mu \mathrm{m}$-thick slices and stained using the hematoxylin and eosin (H\&E) staining (Tolosa, Rodrigues, Behmer, \& Freitas, 2003).

Samples positive for in situ detection of Brachyspira spp. were graded based on histology according to the following lesions: (1) inflammatory infiltrate in the lamina propria of the intestine; (2) intestinal crypts distended by inflammatory cells and cellular debris; and (3) presence of spirochetes.

\section{PAS staining and goblet cell count}

The $5-\mu \mathrm{m}$ - thick sections of cecal fragments from all 129 birds were stained with periodic acid-Schiff (PAS) to study the goblet cells according to the method proposed by Culling, Allison and Barr (1985).

The sections of the cecal fragments were analyzed under a white light microscope and the number of goblet cells in 10 random fields were counted and an average value was taken.

IHC

For $\mathrm{IHC}$, the positive and negative controls used were provided of cecum with positive and negative bacterial cultures for Brachyspira respectively, obtained in a previous study in the same laboratory. 
Fragments of the cecum were fixed in $10 \%$ buffered formalin solution and processed for paraffin embedding. After this procedure, 5 - $\mu$ m-thick histological sections were mounted on silanized slides. The tissue sections were deparaffinized lusing xylene thrice for 10 minutes each, twice with 100\% ethanol for five minutes each, and once with $95 \%$ ethanol followed by $70 \%$ ethanol, each time for five minutes. The slides were treated with hydrogen peroxide and then washed with $100 \mathrm{mM}$ Tris, pH 7.2, 0.9 M NaCl, $0.1 \%$ sodium dodecyl sulfate solution. Antigenic recovery was performed with the aid of trypsin-based enzymes and heat using the microwave. To block nonspecific reactions, the slides were treated with 5\% skim milk. Primary rabbit polyclonal antibody specific for Brachyspira spp. was added to the slide. The secondary antibody compound from the DAKO LSAB kit (Dako EnVision + Dual Link System-HRP; Agilent, USA) was used. As a developer of the reaction, the chromogen, 3-amino-9ethylcarbazole, was used. The adjacent tissue was counterstained with Mayer's Hematoxylin. The slides were mounted with aqueous medium (Faramount).

\section{$\mathrm{FISH}$}

To perform FISH, four probes were used: one for the genus Brachyspira and three other species-specific probes synthesized commercially (Invitrogen, USA). Following were the target sequences: the 16S rRNA region for Brachyspira spp:: ATTAGTCCATGTTTCCAT; for $B$. Hyodysenteriae, the 23S rRNA region: CTCACGATGAACCTTCGAC; forB.Pilosicoli, the 16S rRNA region: GCTCATCGTGAAGCGAAA; and for $B$. Intermedia, the nox gene region: ATAAACATCAGGATCTTTGC (Schmiedel, et al.,
2009; Boye, et al., 1998; Phillips \& Hampson, 2006). All were labeled with Alexa Fluor 555 fluorochrome (Thermo Fisher, USA) and were purified using HPLC.

Five- $\mu$ m-thick sections mounted on silanized slides were deparaffinized using xylene twice for 10 minutes each, and then rehydrated for 5 minutes in each of the following solutions: absolute ethanol, $90 \%$ ethanol, $80 \%$ ethanol, $70 \%$ ethanol and distilled water. The slides were dried at room temperature and then mounted on Coverplates (Thermo Fisher, cat no 72110017, Waltham, MA, USA) and fitted to a hybridization chamber (Coverplate slide rack, Thermo Fisher, cat no 73310017). For this step, each slide was incubated with $99 \mu$ of hybridization buffer $(100 \mathrm{mM}$ Tris, $\mathrm{pH} 7.2,0.9 \mathrm{M} \mathrm{NaCl}, 0.1 \%$ sodium dodecyl sulfate) added to $1 \mu \mathrm{l}$ of solution containing $100 \mathrm{ng}$ of probe at $45^{\circ} \mathrm{C}$ for 16 hours. After this period, the slides were washed thrice with hybridization buffer prewarmed to $45^{\circ} \mathrm{C}$, then washed three times with washing solution prewarmed to $45^{\circ} \mathrm{C}(100 \mathrm{mM}$ Tris, $\mathrm{pH} 7.2,0.9 \mathrm{M}$ $\mathrm{NaCl})$, and lastly washed in ultrapure water for two minutes and dried in an oven at $45^{\circ} \mathrm{C}$. The slides were mounted using mounting medium suitable for fluorescence microscopy and immediately assessed under a fluorescence microscope (Olympus, FSX 100, Japan) using a suitable filter for the fluorochrome.

\section{Statistical analysis}

The mean number of goblet cells was evaluated in all animals used in the study (129) and compared in isolation with the samples positive for IHC and FISH. The chi-square test was used, and $p<0.05$ determined statistical significance. 
The results were also compared between $\mathrm{FISH}$ and $\mathrm{IHC}$ techniques aiming at their correspondence with each other (whether the samples positive in IHC as well as in FISH). The chi-square test was used, and $\mathrm{p}<$ 0.05 determined statistical significance.

\section{Results}

Upon histological analyses, the following lesions were observed: inflammatory infiltrate composed of heterophils and eosinophils in the lamina propria; intestinal crypts distended by inflammatory cells and cellular debris (Figure 1B and 1C); and the presence of delicate basophilic spirochetes in the lumen of the crypts, between the villi and at the apex of the intestinal villi. The histological lesions were graded as follows: (1) inflammatory infiltrate in the lamina propria of the intestine; (2) intestinal crypts distended by inflammatory cells and cellular debris; and (3) presence of spirochetes (Table 1).

Table 1

Grading of histological lesions observed in the 86 FISH-positive broiler cecum samples (mean count of 5 fields per high magnification)

\begin{tabular}{cccccc}
\hline Dilatation of intestinal crypts by & $\begin{array}{c}\text { No Change/ } \\
\text { absent }\end{array}$ & $\begin{array}{c}\text { Discrete/ } \\
\text { rare }\end{array}$ & $\begin{array}{c}\text { Light/ } \\
\text { multifocal }\end{array}$ & $\begin{array}{c}\text { Moderate/ } \\
\text { coalescing }\end{array}$ & $\begin{array}{c}\text { Accentuated/ } \\
\text { diffuse }\end{array}$ \\
$\begin{array}{c}\text { cellular debris and inflammatory cells } \\
\text { Bacteria with a spirochetal shape }\end{array}$ & 6 & 10 & 0 & 1 & 0 \\
Inflammatory infiltrate heterophilic & 1 & 48 & 26 & 6 & 0 \\
\end{tabular}

In PAS staining, the goblet cells were intensely stained in magenta (Figure 1A). Goblet cell counts revealed an increase in these cells for IHC and FISH-positive samples when compared to negative samples (Table 2).

\section{Table 2}

Goblet cell count (mean count of 10 fields per high magnification) obtained using periodic acid Schiff technique compared to FISH and IHC techniques ( $\mathrm{N}=129)$.

$\begin{array}{cccc} & \text { Goblet cell count in FlSH* } & \text { Goblet cell count in IHC** } & \text { Total } \\ \text { Negative } & 2214 a & 2399 a & 4613 \\ \text { Positive } & 3984 b & 3799 b & 7783\end{array}$

*Fluorescent in situ hybridization; **Immunohistochemistry. Different lowercase letters in the columns indicate statistical difference using Chi-square test $(p<0.05)$. 
IHC was positive for 82 of 129 samples tested. The immunoreactivity was classified as either weak (25/82), moderate (27/82), or marked (30/82). Immunolabelling was present on the top of the villi and in the lumen of Lieberkühn's glands (Figures 1D-1F).

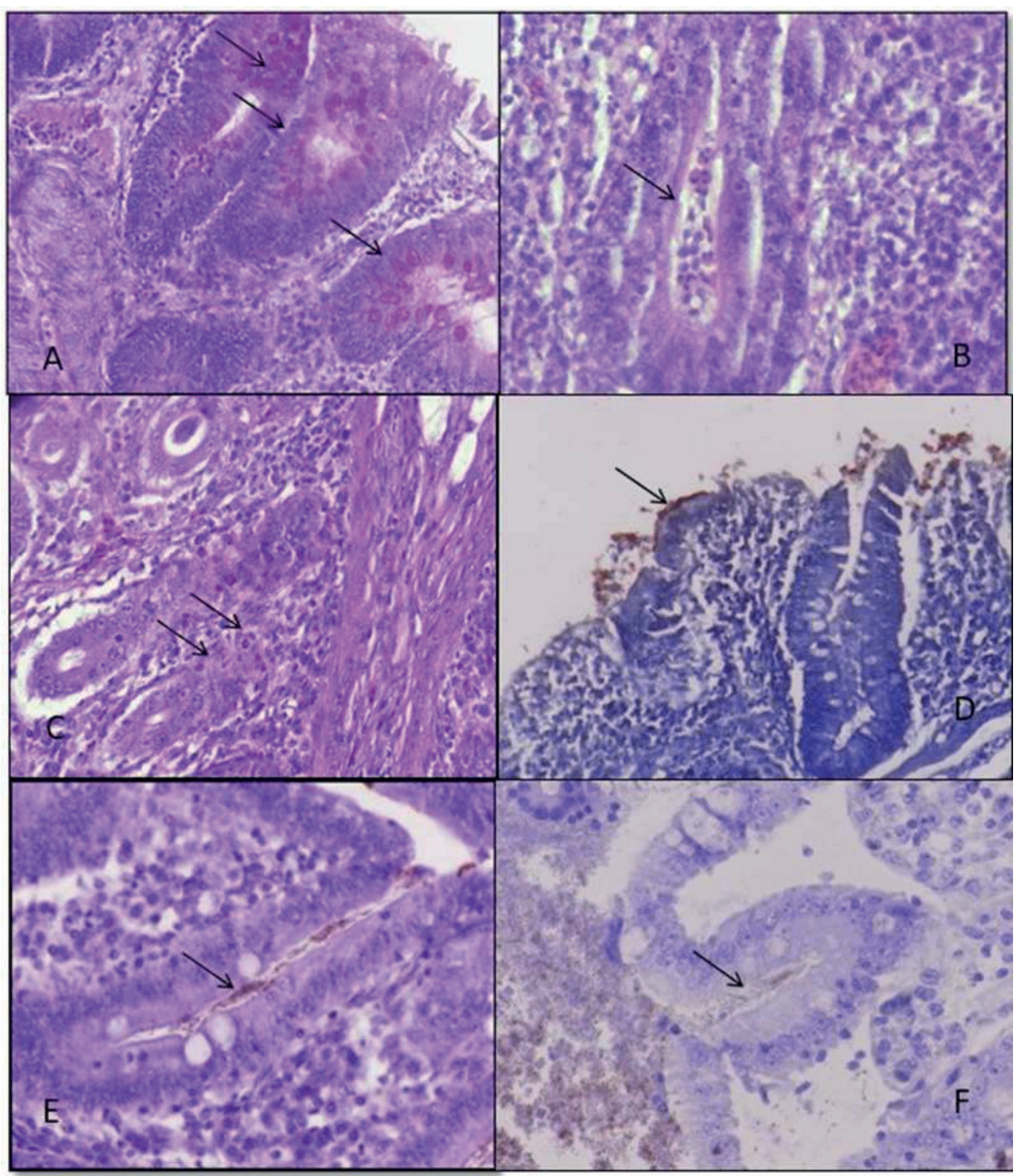

Figure 1. Photomicrographs of the histological lesions of the cecum of the birds and photomicrographs with positive staining for Brachyspira spp. by IHC technique. (A) Goblet cell hyperplasia (arrows) PAS (20× magnification). (B) Intestinal crypt dilated by cell debris (arrow) H\&E (40× magnification). (C) Heterophilic inflammatory infiltrate in the lamina propria (arrows) H\&E (20x magnification). (D) Positive immunoreactivity for Brachyspira spp. (brush border; arrow) (20x magnification). (E) Positive immunoreactivity for Brachyspira spp. in the intestinal mucosa (arrows) (40x magnification). (F) Positive immunoreactivity in intestinal crypts (60× magnification). 
The Brachyspira genus probe was tested individually on 129 samples revealing 86 positive samples. An experiment was performed where only the samples positive for Brachyspira genus were tested for the following species: B. hyodesenteriae, B. intermedia and B. pilosicoli. A total of 80,75 , and 56 samples were found to be positive for B. intermedia, B. hyodesenteriae, and B. pilosicoli, respectively (Figure 2).

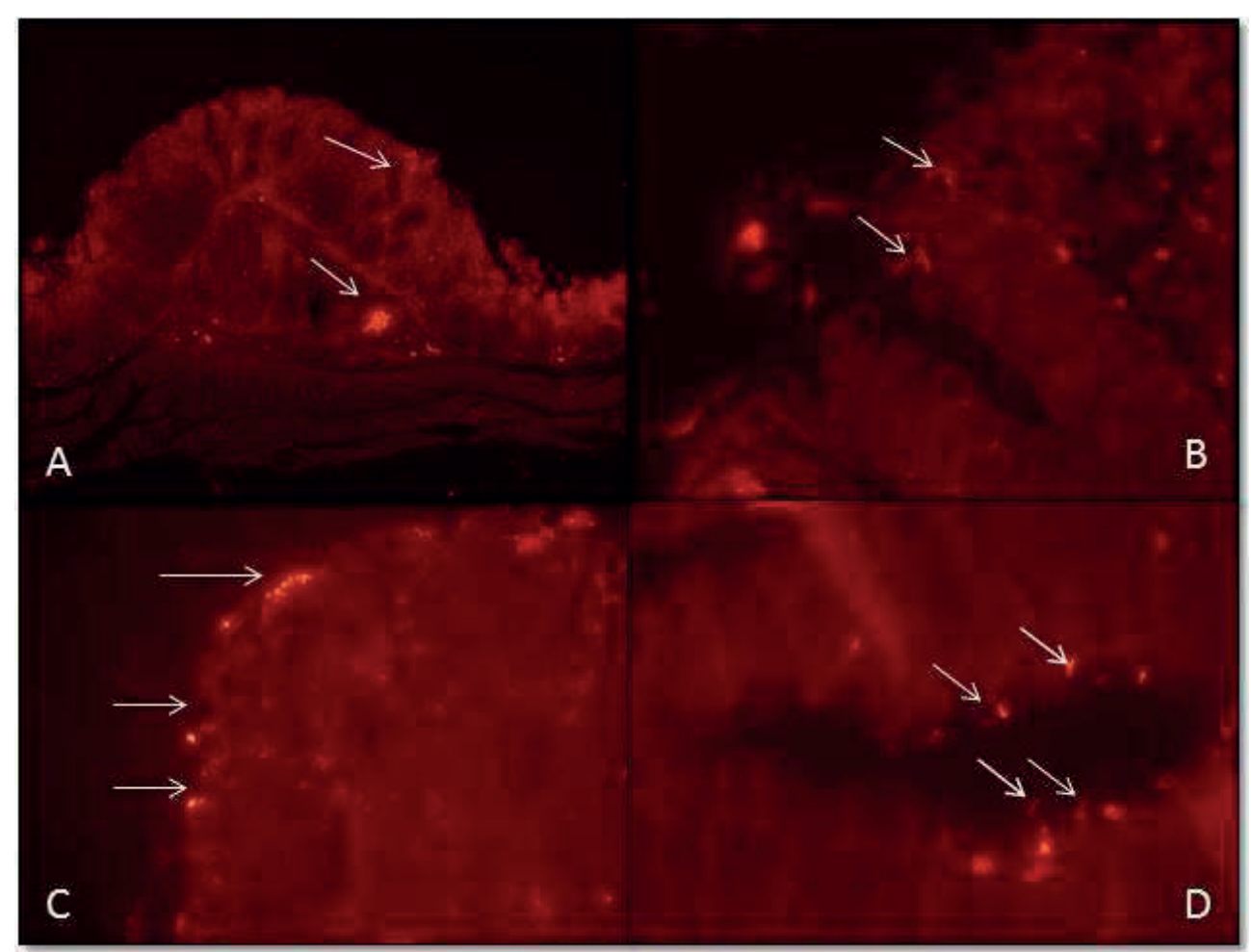

Figure 2. Photomicrographs with positive staining for Brachyspira in the cecum of chickens using fluorescence in situ hybridization (FISH) technique. (A) Positive staining for Brachyspira hyodysenteriae in mucosa (arrow) and in lymphoid tissue in the submucosa (GALT; arrow) (4x magnification). (B) Positive staining for Brachyspira spp. in the apical border of cells lining the intestinal mucosa (arrows) (20x magnification). (C) Positive staining for B. pilosicoli at the apex of the intestinal mucosa (10× magnification). (D) Positive staining for B. intermedia associated with the intestinal crypt (40× magnification).

Significant compatibility was observed between the IHC and FISH techniques (Table 3). All IHC-positive samples were FISH- positive. The number of positive samples for FISH was slightly higher than that that for IHC (86 FISH-positive and 82 IHC-positive). 
Table 3

Comparison of IHC and FISH techniques for the identification of Brachyspira spp. (N = 129).

\begin{tabular}{|cccc|} 
& IHC* $^{*}$ & FISH** & Total \\
\hline Negative & $47 a$ & $43 a$ & 90 \\
\hline Positive & $82 b$ & $86 b$ & 168 \\
\hline Total & 129 & 129 & 258 \\
\hline
\end{tabular}

*Immunohistochemistry; ** Fluorescent in situ hybridization. Lowercase letters in the columns indicate statistical equality using Chi-square test $(p<0.05)$ in relation to the techniques tested.

\section{Discussion}

According to Porter et al. (1998), spirochete lesions in birds consist of mixed infiltration of lymphocytes and plasma cells in the lamina propria, variable degrees of necrosis and hyperplasia of goblet cells, distended crypts with desquamated epithelial cells and spirochetes, and infiltrates of a mixed population of inflammatory cells; these findings corroborates the lesions found using histological methods used in this study. The gradation of these lesions allowed us to conclude that the histological alterations were mostly mild, which may result in low mortality, but could cause considerable loss of overall performance of the affected birds.

An increase in the number of goblet cells is a common alteration observed in animals infected with Brachyspira spp. (Feberwee, et al., 2008; Shivaprasad \& Duhamel, 2005; Jensen, Stanton, \& Swayne, 1996). The presence of bacteria leads to a greater production of mucus as a form of defense against the invading microorganism (Pusztai \& Greer, 1984).

Positive immunoreactivity was present mainly in the lumen of crypts similar to that observed by Venkatakrishnan (2017), who visualized $B$. hyodysenteriae in the colon of pigs using immunofluorescence, which resulted in strong labeling of the bacterium in the lumen of intestinal crypts in close association with the epithelium and in the goblet cells.

Paulovich et al. (2004), in an experimental infection with B. pilosicoli of one-day-old chicks, observed positive immunoreactivity in the intestinal epithelium toward the lumen, forming a dark border composed of the spirochetes (false brush border). This colonization pattern was also observed in the samples used in this study.

Another pattern found in the $\mathrm{IHC}$ samples was the presence of free spirochetes in the intestinal lumen. Paulovich et al. (2004) have speculated that the histopathological processing could have caused the presence of bacteria in the intestinal lumen. Artifacts of sample processing could be considered among the factors that could explain this "shedding" of adhered bacteria.

FISH showed a large number of mixed infections of more than one tested species. Hess et al. (2017) identified that birds can become infected with different species of Brachyspira during their lives, with a change in dominant species over time. This is because of the introduction of different species from 
the environment, leading to continuous reinfections of the birds, where one strain does not interfere with heterologous infection.

Many apathogenic Brachyspira species have been identified in birds, including $B$. innocens, B. murdochii, and B. pulli (Feberwee et al., 2008). Among the pathogenic species described in birds, $B$. alvinipulli is reported in low frequency in the field, with few isolations and outbreaks reported in literature (Phillips \& Hampson, 2006, Feberwee et al., 2008), and was therefore not a target of this study. Thus, we can conclude that other untested species may also infect birds.

All samples positive in IHC were also positive in FISH. The FISH technique (86/129) was slightly more sensitive than the IHC technique (82/129). According to Boye et al. (1998), the FISH technique is capable of detecting even a single bacterial cell as long as it is present in the histological section visualized, which explains the results obtained.

\section{Conclusions}

The results demonstrated the high frequency of bacteria of the genus Brachyspira in commercial broiler chicken farms in western Paraná. Both the FISH and IHC techniques applied to FFPE tissue samples of chicken cecum efficiently identified the Brachyspira spp., serving as a tool for rapid diagnosis, thereby reducing the time between sample submission and diagnosis.

\section{Acknowledgments}

We would like to thank Fundação Araucária/UFPR for granting the scholarship and Professor Dr. David Barcellos and Dr.
Roberto Mauricio Carvalho Guedes of the Universidade Federal do Rio Grande do Sul and Universidade Federal de Minas Gerais, Brazil, for providing the antibody for Brachyspira used in IHC.

\section{References}

Backhans, A., Jansson, D. S., Aspan, A., \& Fellström, C. (2011). Typing of Brachyspira spp. from rodents, pigs and chickens on Swedish farms. Veterinary Microbiology, 153(1-2), 156-162. doi: 10.1016/j.vetmic. 2011.03.023

Boye, M., Jensen, T. K., Møller, K., Leser, T. D., \& Jorsal, S. E. (1998). Specific detection of the genus Serpulina, S. hyodysenteriae and $S$. pilosicoli in porcine intestines by fluorescent rRNA in situ hybridization. Molecular and Cellular Probes, 12(5), 323330. doi: 10.1006/mcpr.1998

Burrough, E. R., Strait, E. L., Kinyon, J. M., Bower, L. P., Madson, D. M., Wilberts, B. L., Songer, J. G. (2012). Comparative virulence of clinical Brachyspira spp. isolates in inoculated pigs. Journal of Veterinary Diagnostic Investigation, 24(6), 10251034. doi: 10.1177/1040638712457927

Cooper, M., \& Lummas, S. (2017). Antibodies for immunohistochemistry. In Immunohistochemistry and immunocytochemistry essential methods (2nd ed., p. 1-24). Chennai: Wiley Blackwell. Retrieved from https://books.google.com. $\mathrm{br} / \mathrm{books}$ ?id=LPAjDgAAQBAJ\&dq=Antib odies+for+ Immunohistochemistry +in+I mmunohistochemistry+and+Immunocyt ochemistry+Essential+Methods\&hl=enBR\&Ir 
Culling, C. F. A., Allison, R. T., \& Barr, W. T. (1985). Cellular pathology technique (4nd ed.). Vancouver, Canada: Butterworth \& Co. Ltd.

Feberwee, A., Hampson, D. J., Phillips, N. D., La, T., Van Der Heijden, H. M. J. F., Wellenberg, G. J., ... Landman, W. J. M. (2008). Identification of Brachyspira hyodysenteriae and other pathogenic Brachyspira species in chickens from laying flocks with diarrhea or reduced production or both. Journal of Clinical Microbiology, 46(2), 593-600. doi: 10.11 28/JCM.01829-07

Hampson, D. J., Fellstron, M. C., \& Thomson, J. R. (2006). Swine dysentery. In Diseases of swine (9nd ed., pp. 785-805). Ames, lowa: Blackwell Publishing.

Hess, C., Zloch, A., Bilic, I., Hacksteiner, K., Kuchling, S., \& Hess, M. (2017). High prevalence of Brachyspira spp. in layers kept in alternative husbandry systems associated with frequent species variations from end of rearing to slaughter. Avian Pathology, 46(5), 481-487. doi: 10. 1080/03079457.2017.1315049

Illanes, N. V., Tamiozzo, P. J., Cabral, A., Bertone, J., Romanini, S., Yaciuk, R, Pelliza, B. R. (2016). Detection of Brachyspira pilosicoli and other Brachyspira species in Argentine poultry farms. Revista Argentina de Microbiología, 48(1), 67-70. doi: 10.1016/j.ram.2015.12.002

Jensen, N. S., Stanton, T. B., \& Swayne, D. E. (1996). Identification of the swine pathogen Serpulina hyodysenteriae in rheas (Rhea americana). Veterinary Microbiology, 52(3-4), 259-269. doi: 10. 1016/S 0378-1135(96)00076-4
Mappley, L. J., La Ragione, R. M., \& Woodward, M. J. (2014). Veterinary Microbiology, 168(2-4), 245-260. doi: 10.1016/j.vetmic. 2013.11.019

Medhanie, G. A., McEwen, S. A., Weber, L., Sanei, B., Cooley, L., Houghton, S., Guerin, M. T. (2013). Risk factors associated with the colonization of Ontario layer chicken flocks with Brachyspira species. Preventive Veterinary Medicine, 109(34), 304- 311. doi: 10.1016/j.prevetmed. 2012.09.017

Moter, A., \& Göbel, U. B. (2000). Fluorescence in situ hybridization (FISH) for direct visualization of microorganisms. Journal Microbiology Methods, 41(2), 85-112. doi: 10.1016/s0167-7012(00)00152-4

Paulovich, F. B., Borowski, S. M., Driemeier, D., Razia, L. E., Coutinho, T. A., Prates, A. B. H.,... Barcellos, D. E. S. N. (2004). Evaluation of the pathogenicity of Brachyspira pilosicoli strains by conventional histopathological techniques and by immunohistochemistry. Pesquisa Veterinária Brasileira, 24(3), 144-148. doi: 10.1590/s0100-736x2004000300005

Phillips, N. D., La, T., \& Hampson, D. J. (2006). Development of a two-step nested duplex PCR assay for the rapid detection of Brachyspira pilosicoli and Brachyspira intermedia in chicken faeces. Veterinary Microbiology, 116(1-3), 239-245. doi: 10. 1016/j.vetmic.2006.03.020

Porter, R. E. (1998). Bacterial enteritides of poultry. Poultry Science, 77(8), 11591165. doi: $10.1093 / p s / 77.8 .1159$

Pusztai, A., \& Greer, F. (1984). Effect of dietary legume proteins on the morphology and secretory responses to the rat small 
intestine. Protides of the Biological Fluids, 32, 347-350. doi: 10.1016/B978-0-08-03 1739-7.50088-4

Rojas, P., Petrich, A., Schulze, J., Wiessner, A., Loddenkemper, C., Epple, H. J.,... Moter, A. (2017). Distribution and phylogeny of Brachyspira spp. in human intestinal spirochetosis revealed by FISH and 16S rRNA-gene analysis. Anaerobe, 47, 25-32. doi: 10.1016/j.anaerobe.2017.03.012

Schmiedel, D., Epple, H. J., Loddenkemper, C., Ignatius, R., Wagner, J., Hammer, B.,... Moter, A. (2009). Rapid and accurate diagnosis of human intestinal spirochetosis by fluorescence in situ hybridization. Journal of Clinic Microbiology, 47(5), 1393-1401. doi: 10.1128/JCM.02469-08

Shivaprasad, H. L., \& Duhamel, G. E. (2005). Cecal spirochetosis caused by Brachyspira pilosicoli in commercial turkeys. Avian Diseases, 49(4), 609-613. doi: 10.1637/7383-052005.1
Song, Y., \& Hampson, D. J. (2009). Development of a multiplex qPCR for detection and quantitation of pathogenic intestinal spirochaetes in the faeces of pigs and chickens. Veterinary Microbiology, 137 (1-2), 129-136. doi: 10.1016/j.vetmic.20 08.12 .020

Tolosa, E. M. C., Rodrigues, C. J., Behmer, O. A., \& Freitas, A. G., Neto. (2003). Manual de técnicas para histologia normal e pathologia (2a ed., pp. 20-41). Barueri: Manole.

Venkatakrishnan, V., Quintana-Hayashi, M. P., Mahu, M., Haesebrouck, F., Pasmans, F., \& Lindén, S. K. (2017). Brachyspira hyodysenteriae infection regulates mucin glycosylation synthesis inducing an increased expression of core-2 o-glycans in porcine colon. Journal of Proteome Research, 16(4), 1728-1742. doi: 10.1021/ acs.jproteome.7b00002 